\title{
Simulation Of Flood Mapping in Amasing Kali Village Using HEC-RAS 2D
}

\author{
Ichsan Rauf ${ }^{1 *}, \operatorname{Imran}^{1}$, and Idhar Sahdar ${ }^{2}$ \\ ${ }^{1}$ Civil Engineering Departement, Universitas Khairun, Ternate, Indonesia \\ ${ }^{2}$ BWS, Public Works Departement, North Maluku, Indonesia
}

\begin{abstract}
This study aims to map the distribution of floods that occurred due to the overflow of the Amasing Kali River on Bacan Island, South Halmahera. The magnitude of the flood as an input in the Watershed (DAS) system was analyzed using the Nakayasu unit synthetic hydrograph (HSS) method, while the morphometric characteristics of the watershed were analyzed by extracting digital elevation model data (Digital Elevation Model, DEM) using a Geographic Information System (GIS) application. The simulation of flood distribution with return periods of 2, 5, 10 and 25 years was carried out by applying the HecRAS 2D application. The mapping of the analysis and simulation results of this study shows that the potential flood-affected areas are on the north and south sides of Amasing Kali village with inundation heights varying between $0.50 \mathrm{~m}-1.50 \mathrm{~m}$.
\end{abstract}

Keywords: Flood mapping, HecRAS 2D, GIS.

\section{Introduction}

Changes in land use as a result of human growth and global climate change are factors that cause an increase in the frequency of flood problems that occur throughout the world. In terminology, a flood is a condition in which an area is inundated by water due to overflow that exceeds the capacity of the water disposal in the area and causes physical, social, and economic losses [1]. This definition shows that floods can have a negative impact on the growth of an area because of disrupting community activities.

Data released by Indonesia's National Disaster Management Agency (Indonesian: Badan Nasional Penanggulangan Bencana (BNPB)) indicates that there were 1064 flood events out of a total of 2921 natural and non-natural disasters that occurred throughout Indonesia in 2020. Meanwhile, in the period from January 1 to March 31 in 2021, 337 flood events have been recorded from a total of 763 disaster events. These data show that flood is the dominant disaster in Indonesia and continues to increase both in terms of intensity and frequency. The floods that occurred throughout Indonesia not only caused material losses but also resulted in the loss of life.

Amasing Kali River is one of the largest rivers on Bacan Island, South Halmahera Regency. In 2017, there was a large flood that inundated several villages, such as Amasing Kali, Mandawong, North Amasing Kota, West
Amasing Kota, Labuha, and Gandasuli. The overflow of the Amasing Kali River not only caused a $50 \mathrm{~cm}$ high inundation that led approximately 700 families to evacuate but also damaged infrastructures, such as roads and bridges connecting Kupal and Tembal Villages.

The large negative impact caused by this flood event requires integrated handling efforts to reduce the losses caused by this event both structurally and nonstructurally. Determination of actions in flood control must be based on the behavior of the flood in the area, considering that flood is strongly influenced by the morphology of each watershed. The extent of this spatial and temporal variability requires a more detailed regional approach to flood-prone areas as the basis for making flood control policies.

The rapid development of computerization and information systems provides a new approach to controlling flood phenomena. Geographic Information System (GIS) becomes a tool that provides solutions to manage spatial data (Aronoff, 1989). The use of GIS to reduce spatial variability is a solution in policy-making for watershed management because current advances in geographic information systems and imaging can help stakeholders in making policies related to watershed management [2]. In addition, by integrating GIS with other applications, GIS is able to model the hydrological mechanisms that occur in a watershed area. For example, the use of aerial imagery and GIS can be

\footnotetext{
* Corresponding author : ichsan_rauf@unkhair.ac.id
} 
utilized to determine the priority level of groundwater criticality in a watershed according to its morphometry [3]. Furthermore, the integration of GIS and GAMES (the Guelph Model for Evaluating the Effects of Agricultural Management Systems on Erosion and Sedimentation) can be applied to assess the mechanism of sediment transport in watersheds [4].

Policymaking in flood control definitely requires a basis that can model the behavior of the flood. Climate change and watershed morphology are variables that are strongly influenced by space and time (Serban \& Galie, 2006). Therefore, understanding the risk of a flood event in the future will help in reducing the resulting impacts. For this reason, mapping of flood areas based on their functions is very important in flood control, as stated by Klemešová et al. that flood mapping plays an important role in policies regarding flood control [5]. In addition to providing information related to the potential vulnerability of an area, mapping of flood areas can also be used as an evaluation material to find out the advantages and disadvantages of the measures taken in flood control.

The integration of GIS and Hec-RAS (Hydrology Engineers Corps River Analysis System) becomes one of the methods that have been widely used to model flood distribution in various regions. In modeling the distribution of floods, Hec-RAS can be applied to model its hydraulic behavior based on hydrological simulations from the morphometric characteristics of the watershed. Meanwhile, GIS is used to analyze the morphometric characteristics of a watershed and map the results of the flood modeling. For this reason, this study aims to carry out a similar approach to modeling the distribution of floods that occurred in Amasing Kali Village.

\section{Methods}

\subsection{Research Location}

The object of this study is Amasing Kali River which is astronomically located at coordinates $12^{\circ} 55^{\prime} 56^{\prime \prime} \mathrm{N}$ and $114^{\circ} 56^{\prime} 44^{\prime \prime}$ E. Administratively, this river is located on Bacan Island, specifically in South Halmahera Regency, North Maluku Province, as shown in Figure 1.

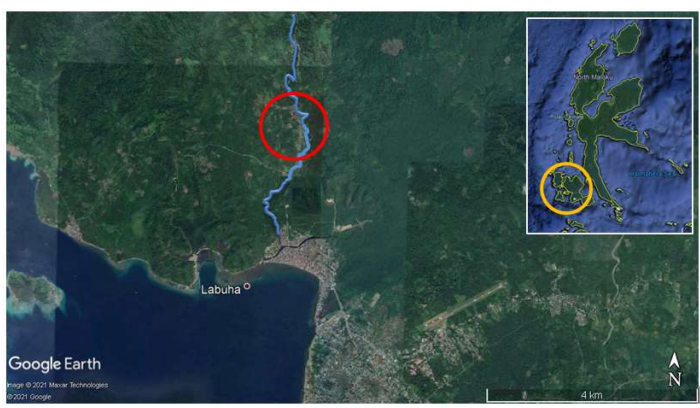

Fig.1. Research location in Bacan Island

$\mathrm{L}=20 \mathrm{~mm}$ $\mathrm{r}=10 \mathrm{~mm}$

\subsection{Data Collection and Analysis}

This study was a quantitative research with a simulation approach. Data needed for the analysis were hydrological and hydraulic data. These data were obtained through direct measurements in the field and became primary data in this study. Meanwhile, secondary data were collected from relevant agencies.

Flood runoff discharge as input in the watershed system was analyzed through a statistical approach by analyzing the frequency of rainfall, referring to the stages proposed by Triatmodjo, namely grouping rainfall data, conducting frequency analysis, testing statistical parameters, and testing homoscedasticity [6]. In this study, the applied rainfall data were the daily maximum rainfall series data for 10 years $(2011-2020)$ obtained from the Meteorological Station of Oesman Sadik Airport, Labuha. The flood discharge was analyzed using the rainfall modeling for return periods of $2,5,10$, and 25 years.

The estimated amount of surface runoff due to rainfall was calculated using the Nakayasu Synthetic Unit Hydrograph (NSUH) method. This is based on the results of a study conducted by Safarina et al. that the NSUH method has an error deviation of $22 \%$ for the hydrograph shape and an error rate of $9 \%$ for the flood peak [7]. These values are the lowest compared to other methods, such as GAMA 1, Limantara, and Snyder. Furthermore, the advantage of the NSUH method compared to the Snyder method is that this method presents the concentration time for the flood peak which is more suitable for watershed conditions [8].

The flood distribution simulation was then analyzed using Hec-RAS 2D software, in which the amount of runoff from the hydrological analysis became the input parameter. The geometry model in Hec-RAS was built based on the results of field measurements using a total station tool with reference to SNI 19-6724-2002 regarding Horizontal Control Networks and SNI 196988-2004 regarding Vertical Control Networks. These measurements included measuring the geometry of the river for a length of $3000 \mathrm{~m}$ with cross-sectional intervals taken every $50 \mathrm{~m}$ and measuring the condition of Amasing Kali Village using a tachymeter, carried out along the river flow that is often affected.

The results of the flood discharge analysis using the NSUH method with a flood discharge return period of $2,5,10$, and 25 years became the input values for being used in mapping the distribution of floods that occurred in Amasing Kali Village. To describe the boundary of the flood distribution at peak discharge, the model of the flow was assumed to be steady (steady flow) that enters the upstream of the observed river. The validation of the flood distribution was carried out by comparing the flood events that occurred in 2017, in which the validation was conducted based on the value of rainfall intensity, inundation height, and the total area of inundation.

\section{Results and Discussion}

\subsection{Morphometrics of Watershed in Amasing Kali Village}

The morphometric characteristics of the watershed in Amasing Kali Village were obtained by building a 
spatial model using the Digital Elevation Model (DEM) data obtained from DEMNAS which had a resolution of $8 \mathrm{~m} \times 8 \mathrm{~m}$ or 0.27 arcsecond. The delineation of watershed boundaries was based on information from residents, in which they pointed where the flood overflow started to occur, and then this point became the initial coordinate in topographical measurements.

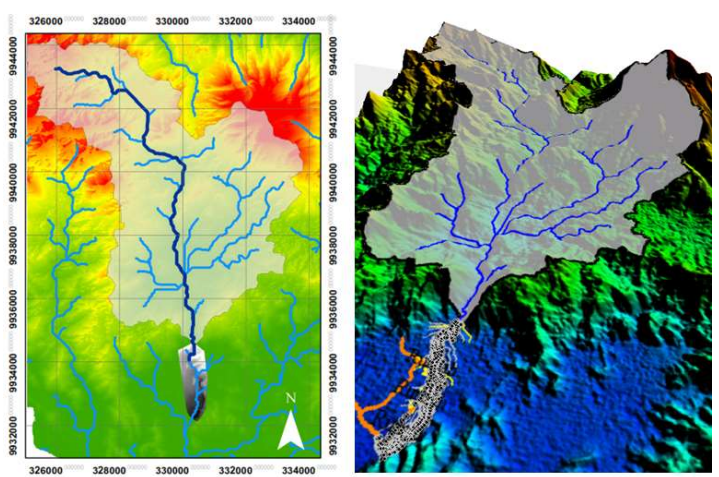

Fig.2. Research site in Bacan Island

The results of spatial modeling of the watershed in Amasing Kali Village and river network that have the potential to contribute to surface runoff at the research site are shown in Figure 2. From the spatial analysis in the Geographic Information System (GIS), the researchers obtained the watershed and river morphometric parameters, consisting of the length of the main river $(\mathrm{L})(15.32 \mathrm{~km})$, the slope of the main river flow $(0.003 \%)$, the total area of the catchment area (A) $\left(42.23 \mathrm{~km}^{2}\right)$, and the slope of the watershed (varying between $2 \%$ - 40\%). In addition, Amasing Kali Village is located in the lowlands at an elevation of 7.00 to 9.30 MASL with a slope that varies between 3\% to 5\%.

\subsection{Hydrological Characteristics of Amasing Kali Village}

In this study, the researchers used the daily maximum rainfall series data for the last 10 years $(2011-2020)$ to analyze the frequency of the rainfall. The data were obtained from the Rainfall Observation Station at Oesman Sadik Airport, as shown in Figure 3. The records of the rainfall showed that the flood event that occurred in February 2015 was influenced by rainfall with an intensity of $127 \mathrm{~mm}$. Meanwhile, for the flood event that occurred in June 2017, the intensity of the rainfall was $121 \mathrm{~mm}$.

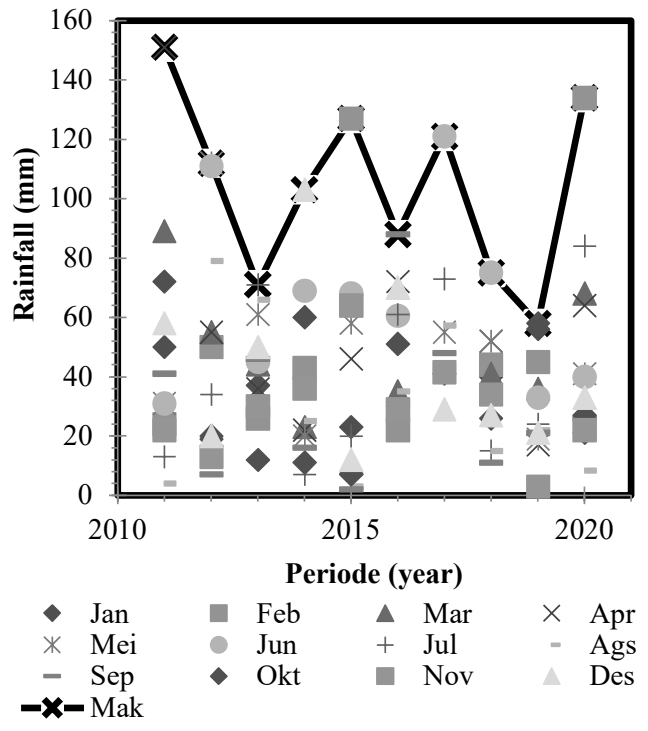

Fig.3. Hourly Rainfall Maximum

Table 1. Rainfall Distribution in Watershed in Amasing Kali Village

\begin{tabular}{|c|r|r|r|r|}
\hline $\mathrm{T}$ & Normal & $\begin{array}{c}\text { Log } \\
\text { Normal }\end{array}$ & \multicolumn{1}{c|}{ Gumbel } & Pearson \\
\hline 2 & 110.20 & 105.21 & 91.69 & 105.35 \\
\hline 5 & 137.88 & 139.17 & 120.22 & 140.66 \\
\hline 10 & 152.37 & 161.13 & 139.11 & 163.18 \\
\hline 25 & 166.47 & 185.81 & 162.97 & 190.07 \\
\hline
\end{tabular}

Determination of the rainfall frequency modeling for return periods of $2,5,10$, and 25 years was carried out by applying several distribution models, such as Normal, Log-Normal, Gumbel, and Log-Pearson. The results of the calculation of the distribution of rainfall for each model are shown in Table 1. Furthermore, from the results of the statistical parameter test, the model that met the criteria was the Log-Pearson distribution model.

To determine a model that can represent the distribution of rainfall that occurs in Amasing Kali Village, the researchers conducted the homoscedasticity testing using the Chi-Squared and SmirnovKolmogorov tests. The results of those tests indicated that the distribution model that should be used as the basis for determining the rainfall modeling was the LogPearson III distribution model. It was indicated by the calculated Chi value, namely 3 . This value is smaller than the $5 \%$ critical Chi value, namely 5.991 . Meanwhile, the result of the Smirnov-Kolmogorov test indicated a value of $0.202\left(\Delta_{\max }\right)$ which is smaller than the critical value of 0.340 ( $\left.\Delta_{\text {critical }}\right)$. By using the rainfall value modeling, the effective rainfall value using the Mononobe method can be calculated, in which the effective rainfall value for 6 hours is shown in Table 2 . 
Table 2. Distribution of Effective Rainfall

\begin{tabular}{|c|c|c|c|c|c|c|c|}
\hline \multicolumn{2}{|c|}{$\begin{array}{c}\text { Effective } \\
\text { Rainfall } \\
\text { (hours) }\end{array}$} & 1 & 2 & 3 & 4 & 5 & 6 \\
\hline $\begin{array}{l}\mathrm{R} 2 \\
(\mathrm{~m} \\
\mathrm{m})\end{array}$ & $\begin{array}{r}105 . \\
35\end{array}$ & $\begin{array}{r}57.9 \\
8\end{array}$ & $\begin{array}{r}15.0 \\
7\end{array}$ & $\begin{array}{r}10.5 \\
7\end{array}$ & 8.42 & 7.11 & 6.21 \\
\hline $\begin{array}{l}\mathrm{R} 5 \\
(\mathrm{~m} \\
\mathrm{m}) \\
\end{array}$ & $\begin{array}{r}140 . \\
66\end{array}$ & $\begin{array}{r}77.4 \\
1\end{array}$ & $\begin{array}{r}20.1 \\
2\end{array}$ & $\begin{array}{r}14.1 \\
1\end{array}$ & $\begin{array}{r}11.2 \\
4\end{array}$ & 9.49 & 8.29 \\
\hline $\begin{array}{l}\mathrm{R} 10 \\
(\mathrm{~m} \\
\mathrm{m})\end{array}$ & $\begin{array}{r}163 . \\
18\end{array}$ & $\begin{array}{r}89.8 \\
0\end{array}$ & $\begin{array}{r}23.3 \\
4\end{array}$ & $\begin{array}{r}16.3 \\
7\end{array}$ & $\begin{array}{r}13.0 \\
3\end{array}$ & $\begin{array}{r}11.0 \\
1\end{array}$ & 9.62 \\
\hline $\begin{array}{l}\mathrm{R} 25 \\
(\mathrm{~m} \\
\mathrm{m})\end{array}$ & $\begin{array}{r}190 . \\
07\end{array}$ & $\begin{array}{r}104 . \\
60\end{array}$ & $\begin{array}{r}27.1 \\
9\end{array}$ & $\begin{array}{r}19.0 \\
7\end{array}$ & $\begin{array}{r}15.1 \\
8\end{array}$ & $\begin{array}{r}12.8 \\
2\end{array}$ & $\begin{array}{r}11.2 \\
1\end{array}$ \\
\hline
\end{tabular}

The results of the calculation of the effective hourly rainfall with the rainfall modeling for return periods are the input parameters for the watershed system in Amasing Kali Village, used in making a hydrograph model with a synthetic unit to analyze the amount of flood discharge. After applying the NSUH method, the researchers obtained that the peak time (Tp) of the flood to occur in the watershed of Amasing Kali Village was 2.34 hours with the hydrograph form as shown in Figure 4. The maximum flood discharges for return periods of $2,5,10$, and 25 years were $153,864 \mathrm{~m}^{3} / \mathrm{s}, 205,032 \mathrm{~m}^{3} / \mathrm{s}$, $237,669 \mathrm{~m}^{3} / \mathrm{s}$ and $276,631 \mathrm{~m}^{3} / \mathrm{s}$, respectively. These results were then used as input flow data for modeling the distribution of floods in Amasing Kali Village.

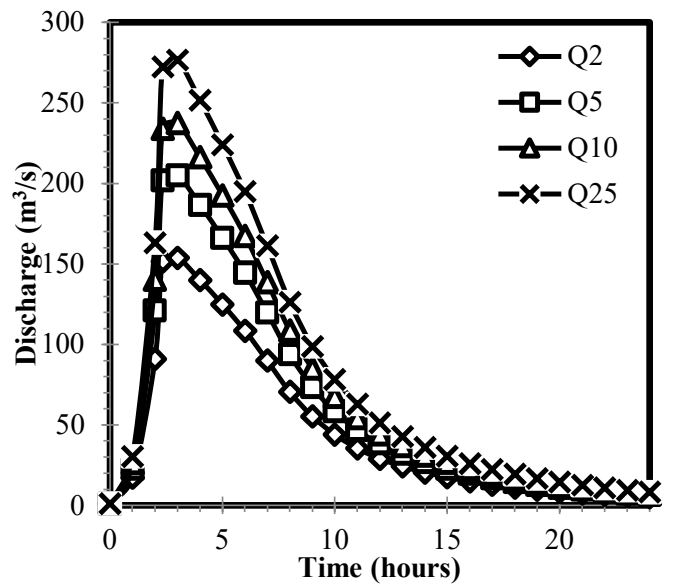

Fig.4. Hydrograph Discharge of Watershed in Amasing Kali Village

\subsection{Flood Mapping in Amasing Kali Village}

For modeling the distribution of floods that occurred in Amasing Kali Village, the researchers used Hec-RAS 5.0.7. Figure $5 \mathrm{a}$ is an illustration of the results of direct field measurements concerning the condition of Amasing Kali Village and its river topography. These data were then used to build a geometric model in HecRAS.
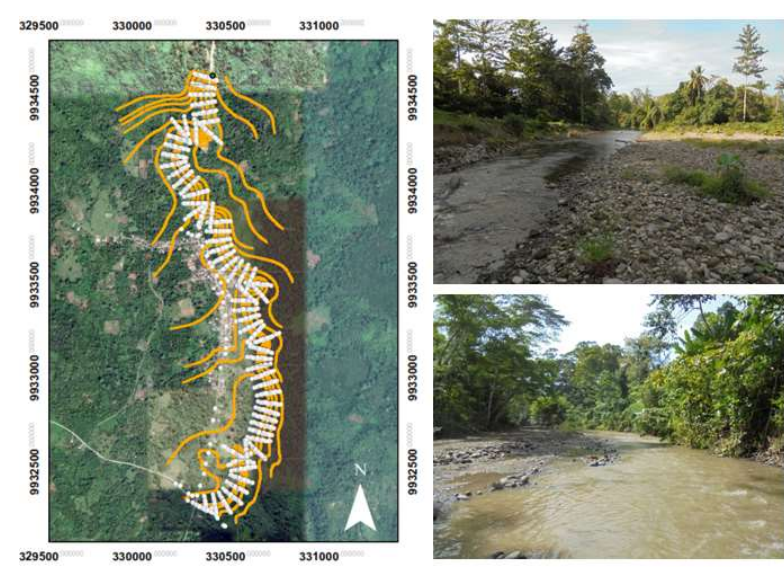

Fig.5. Amasing Kali Village and characteristics of the riverbed and river floodplain

The results of field observations of the flow of the Amasing Kali River show that the pattern of the river flow is meandering, having no vegetation in the main channel, and having silty sand in the riverbed. In addition, for the river border, the upstream area is still dense with vegetation. However, in the middle area, the right side is a residential area and the left side is still dense with vegetation. The characteristics of the area shown in Figures $5 \mathrm{~b}$ and $5 \mathrm{c}$ then became the basis for determining the value of the flow coefficient based on Manning both for rivers and river borders. Determination of the border of the inundation area that occurs due to peak flood discharge was carried out with the assumption that the flow is steady and uniform. This refers to the terms and conditions in the Hec-RAS guide [9].

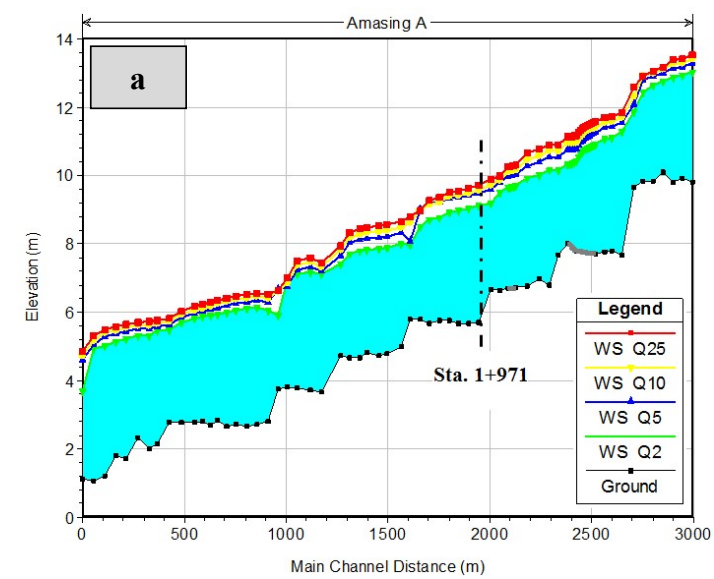

(a) 


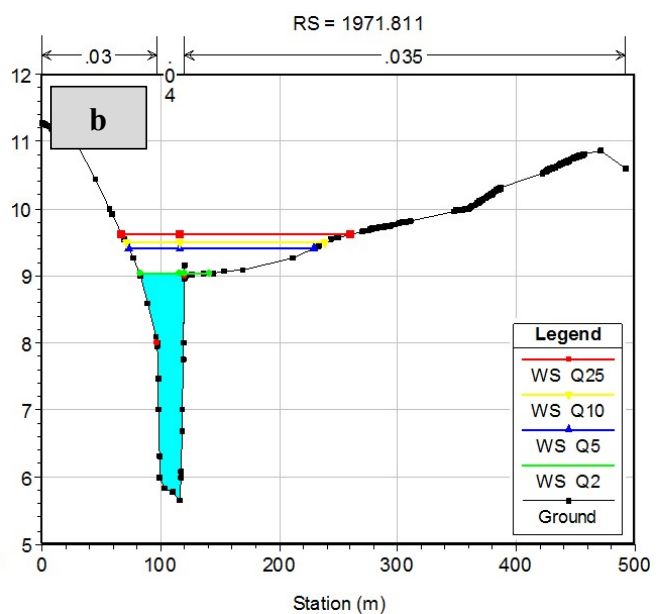

(b)

Fig.6. Water profile for flood discharge: (a) the long section and (b) the cross section

The profile of the floodwater level along Amasing Kali River for each return discharge from the Hec-RAS analysis is shown in Figure 6a. Meanwhile, the profile of the water level profile in the northern part of Amasing Kali Village is shown in Figure 6b. The results of the simulation show that the water level elevation in the northern part of Amasing Kali Village due to discharge at return periods of $2,5,10$, and 25 years is $+9.04 \mathrm{~m}$, $+9.41 \mathrm{~m},+9.49 \mathrm{~m}$, and $+9.61 \mathrm{~m}$, respectively. This causes inundation in Amasing Kali Village with varying depths between $0.5 \mathrm{~m}-1.5 \mathrm{~m}$, as shown in Figure 7 .

The validation of the simulation results was carried out using the data from the flood event in 2017, in which the intensity of rainfall that occurred was $121 \mathrm{~mm} /$ day. The results of the flood analysis show that the amount of flood discharge that occurs is $190,829 \mathrm{~m}^{3} / \mathrm{sec}$ which is equivalent to the flood in the 5-year return period.
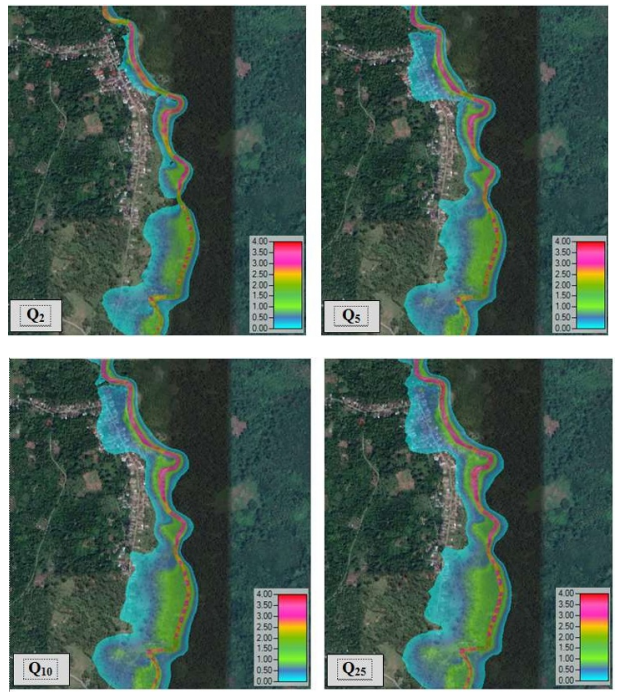

Fig.7. Flood inundation mapping of Amasing Kali Village for the return period of $2,5,10$, and 25 years

Figure $8 \mathrm{a}$ shows the results of flood mapping on RasMapper. These results indicate that the flood distribution tends to be the same as the results of field observations. The inundation height based on the simulation shows that the water level varies between $0.50-1.00 \mathrm{~m}$ and the inundation area is $\pm 39.45 \mathrm{ha}$. Apart from that, the findings in the field through interviews with residents and observations of flood traces in the settlements of residents of Akelaka Village show that the water level in residential areas along the road varies between $0.2-0.5 \mathrm{~m}$, as shown in Figure $8 \mathrm{~b}$. Meanwhile, the flood water level in residential areas along the floodplain of Amasing Kali River varies between $1.00-1.50 \mathrm{~m}$, as shown in Figure 8c.
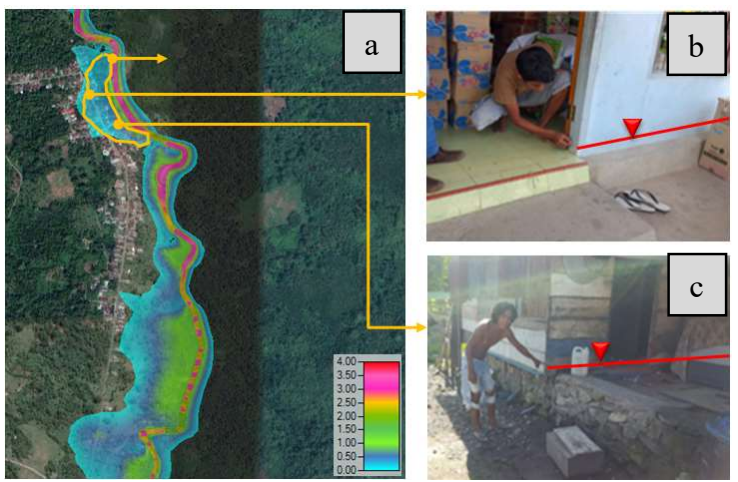

Fig.8. Flood inundation mapping based on flood event in 2017: (a) water level on residential areas across the road and (b) water level on residential areas in the floodplain

\section{Conclusions}

Based on the results of this study, it can be concluded as follows.

1. Simulation and spatial mapping of flood areas can provide visual information on potential flood events in Amasing Kali Village.

2. The height of inundation due to flooding that occurred in Amasing Kali Village varies between $0.5-1.5 \mathrm{~m}$. Furthermore, the total area of inundation due to the flood for return periods of 2 , 5,10 , and 25 years is 30,907 ha, 42,993 ha, 47,995 ha, and 53,729 ha, respectively.

\section{References}

[1] H. Rahayu, I. Wahdiny, A. Utami and M. Asparini, Banjir dan Upaya Penganggulangannya, Bandung: Program for Hydro-Meteorological Risk Mitigation Secondary Cities in Asia (PROMISE), (2009).

[2] Rajeev and S. Singh, "Watershed Management - A GIS Approach," International Journal of Research in Applied, Natural and Social Science (IMPACT: IJRANSS, pp. 109-116, (2016).

[3] K. Avinash, K. Jayappa and B. Deepika, "Prioritization of sub-basins based on geomorphology and morphometric analysis using 
remote sensing and geographic information system (GIS) techniques," Geocarto International, pp. 569-592, (2011).

[4] R. Rudra, W. Dickinson and D. Sharma, "Application GIS in Watershed Management," Journal of Water Management Modelling, pp. 469482, (1993).

[5] K. Klemešová, M. Kolář and I. Andráško, "USING GIS IN THE FLOOD MANAGEMENT - FLOOD MAPS (TROUBKY, CZECH REPUBLIC)," Geographia Technica, pp. 44-53, (2013).

[6] B. Triatmodjo, Hidrologi Terapan, Yogyakarta: Beta Offset, (2008).

[7] A. Safarina, H. Salim, I. Hadihardaja and B. Syahril, "Clusterization of Synthetic Unit Hydrograph Methods Based on Watershed Characteristics," International Journal of Civil \& Environmental Engineering IJCEE-IJENS, vol. 11, no. 6, (2011).

[8] A. Sarminingsih, "Pemilihan Metode Analisis Debit Banjir Rancangan Embung Coyo Kabupaten Grobogan," Jurnal Presipitasi : Media Komunikasi dan Pengembangan Teknik Lingkungan, vol. 15, no. 1, pp. 53-61, (2018).

[9] G. W. Brunner, HEC-RAS, River Analysis System Hydraulic Reference Manual, DAVIS: US Army Corps of Engineers, (2016). 